\title{
PELA DEFESA DAS LIBERDADES TOLERANTES: PROPOSTA DE UM ARRANJO JURÍDICO AO PROBLEMA \\ DA DISPOSIÇÃO DE SÍMBOLOS RELIGIOSOS \\ EM ESPAÇOS PÚBLICOS
}

\begin{abstract}
Juliano Heinen ${ }^{l}$
Resumo: O presente artigo desenvolve um tema candente no cenário nacional. Ele procura discutir quais seriam os limites da laicidade do Estado brasileiro, especialmente frente à disposição de símbolos religiosos em espaços públicos. Para tanto, apresenta-se uma abordagem do tema a partir de um arranjo jurídico que procura dar ao direito em questão uma harmonia entre a liberdade de religião negativa e a positiva e o papel do Poder Público neste sentido. Assim, a partir de uma interpretação constitucional do tema, tenta-se delimitar um arranjo jurídico. Por fim, serão expostos os pressupostos negativos e positivos para a disposição de símbolos religiosos em espaços públicos.

Palavras-chave: Símbolos religiosos; Estado laico; Liberdade religiosa; Tolerância.

Abstract: This paper develops an important topic on the national scene. It discusses the limits of the Brazilian secular state, especially the disposition of religious symbols in public spaces. It presents an approach to the topic from a legal arrangement that seeks to give the right in question some harmony between negative and positive religious freedom and the role of the government in this regard. Thus, through a constitutional interpretation of the theme, it attempts to delimit a legal arrangement. Finally, negative and positive assumptions will be exposed regarding the disposition of religious symbols in public spaces.
\end{abstract}

Keywords: Religious symbols; Secular state; Religious liberty; Tolerance.

1 Procurador do Estado do Rio Grande do Sul. E-mail: julianoheinen@hotmail.com

Debates do NER, Porto Alegre, ANo I4, N. 24, P. I65-I94, JUl./DeZ. 2013 


\section{INTRODUÇÃO}

A questão da disposição de símbolos religiosos em espaços públicos reclama uma resposta que não pode ser simples, tendo em vista envolver valores metajurídicos e a incidência de conhecimentos científicos propedêuticos. Ademais, a discussão sobre o tema tende a ser o debate mais visível, mas, em nossa opinião, o mais reduzido no que se refere aos efeitos sociais. E isso será percebido com muita nitidez na exposição feita a seguir.

O que se quer dizer é que a temática acerca das liberdades laicas e das inúmeras variantes e ligações que permeiam o tema, possivelmente, seja um estudo ainda tímido no limiar do campo do saber jurídico, por exemplo. No entanto, ele possui reflexos em inúmeras áreas, sendo, repita-se, a disposição de símbolos religiosos em espaços estatais a menos significativa das discussões em termos de repercussão coletiva ${ }^{2}$.

Importa, pois, inferir que a discussão comporta um debate (axiológico, por certo) muito mais profundo e anterior, que envolve o balanceamento do direito fundamental à prática religiosa em face ao Estado (lato sensu) laico ou não confessional. Em termos ainda mais específicos, a resolução desta problemática passa, necessariamente, pela interpretação dos limites do âmbito de proteção dos dispositivos constitucionais que envolvem os bens jurídicos mencionados. Eis o ponto central.

Para tanto, pretende-se debater a questão por meio do método de abordagem dedutivo, que busca focar o seu objeto do geral para o particular, razão pela qual serão enfrentadas, num primeiro momento, as questões teóricas fundamentais e de base ao objeto da consulta. Ademais, o artigo será estruturado pela via do método de procedimento histórico-crítico e comparativo, sendo que a técnica de pesquisa utilizada é a bibliográfica, a qual atua por meio de uma revisão pertinente dos temas centrais à pesquisa, cuja fundamentação é baseada em documentação direta e indireta. Essa técnica é, ainda, aliada à pesquisa jurisprudencial que se liga com a temática em pauta.

Aliás, é importante ter em mente que o tema será debatido a partir de uma perspectiva jurídica, notadamente constitucional. E a releva dar vazão a

2 Conforme já alertamos em outro trabalho deste mesmo periódico (Heinen, 2009, p. 255).

Debates do NER, Porto Alegre, ANo I4, N. 24, P. I65-I94, JUl./Dez. 2013 
um debate desta espécie, tendo em vista que, ao fim e ao cabo, quem dará a última palavra, ao menos em nível de realidade institucional - que é o que se aproxima efetivamente da vida das pessoas, ou seja, daquilo que se pode ou não pode fazer - é a Suprema Corte brasileira. Assim, causaria surpresa (para dizer o mínimo) caso algum cientista social, p. ex., pesasse que o tema somente ou precipuamente envolve questôes antropológicas ou sociais, deixando de lado justamente o debate jurídico, porque será no espaço jurídico que se saberá se é possível ou não colocar um artefato religioso em um espaço público, e em que medida.

\section{COLOCANDO AS COISAS NOS SEUS DEVIDOS TERMOS}

A visualização do panorama atual é deveras conhecida do público-leitor de um periódico como Debates do NER, o que facilita compreender que o cenário atual, tanto jurídico como social, encontra uma nova vazão de valores que tendem a firmar um novo advento do Estado dito "laico", seja na sua forma de estruturação, seja na forma de solução da problemática. A separação entre Estado e Igreja pode ser percebida como um marco histórico consolidado, ou seja, firmado a partir da compreensão de que religião e política não se confundem ${ }^{3}$. O Estado laico pode ser conceituado como aquele que possui sua legitimidade na soberania popular, e não em premissas religiosas, sendo considerado um princípio constitucional (Huaco, 2008, p. 40). Sendo assim, estabelece um paradigma a todo o sistema jurídico. Enfim, é aquele que não possui uma religião oficial, porque não se posiciona institucionalmente em prol de nenhuma delas. Mantém-se neutro e imparcial no que se refere aos temas religiosos, o que não o impede de atuar em prol de uma harmonização das religiôes, p. ex. (Asad, 2009, p. 23).

O Estado já não estabelece (ou não deveria estabelecer) suas bases sobre a religião, sendo que esta atuaria em instâncias próprias, ao mesmo tempo em

3 Podemos perceber isso em vários autores, como, p. ex., em John Locke (1990, p. 18-19), que afirma a necessidade de que fossem distinguidos os limites entre a religião e a política. Somente deve ser feita uma ressalva: Locke prega uma tolerância limitada, não estendida aos católicos e ateus, o que não pode, nos dias de hoje, ser aceito.

Debates do NER, Porto Alegre, Ano I4, N. 24, P. I65-I94, JUl./Dez. 2013 
que não poderia negá-la ou optar pelo ateísmo. Em verdade, o Estado que se diz laico prima pela efetivação do princípio da igualdade (Huaco, 2008, p. 46) permanecendo neutro (repita-se: nem religioso, nem ateu).

O conflito entre a liberdade religiosa negativa - sedizente "secular" - e positiva - daqueles que se dizem "confessionais" - tem de ser harmonizado pela via da tolerância e segundo o princípio da concordância. Logo, a liberdade negativa de confissão religiosa jamais pode prevalecer em absoluto em face à liberdade religiosa positiva, de quem quer praticá-la.

Ao se tratar da liberdade religiosa negativa e positiva, deve-se ter em mente que o direito constitucional de um "Estado laico", com suas normas de dignidade, de liberdade de consciência, de religião e de culto, assenta-se no pressuposto básico de que muitas pessoas procuram o sentido existencial e ético da vida por meio de uma referência ao "Criador". E esta procura deve ser levada a cabo pelos indivíduos e comunidades, mesmo que envolva discordâncias para com outros nos planos teológico, filosófico e confessional, resultantes da tendência humana de dar sentido à vida, tanto individual quanto coletivamente (Machado, 2013, p. 144). Destaca-se, pois, que o Estado Constitucional não pode ser indiferente a esta questão, restando-lhe uma obrigação negativa, ou seja, de abstenção, criando um perímetro de autonomia às pessoas em torno desta liberdade de crença, de consciência e de cultos, num rol pluralista de possibilidades, ao mesmo tempo que deve criar meios a esta mesma autonomia - perspectiva positiva.

Há posiçōes doutrinárias segundo as quais o Estado Constitucional não pode ser absolutamente neutro, do ponto de vista ético e religioso, pois isto conduziria a uma negação dos seus próprios valores positivos, tais como: dignidade, igualdade, liberdade, responsabilidade, democracia, separação de poderes, verdade, racionalidade, justiça e solidariedade. Uma vez que

4 Sobre a necessidade de se estabelecer o parâmetro isonômico no limiar do Estado Democrático de Direito, consultar a obra de Pontes de Miranda (1945). O livro estrutura uma forte base teórica acerca da importância da democracia em um Estado de Direito, premissa que não pode ser apartada da igualdade do ser humano, vista não somente como direito, mas como um requisito para o Estado.

Debates do NER, Porto Alegre, ANo I4, N. 24, P. I65-I94, JUl./DEZ. 2013 
estes valores supõem uma tomada de posição moral e ética, tal neutralidade estatal geraria um constitucionalismo contraditório5.

Com esta posição, confirma-se o próprio texto expresso no art. $19 \mathrm{da}$ Constituição Federal, ao estabelecer as bases do princípio da laicidade, que tem como pano de fundo os valores e princípios confirmadores do Estado Constitucional, como uma demonstração clara de que é impossível separar, de forma absoluta, as visões que se tem do mundo, dos valores, princípios e regras que organizam juridicamente os diferentes aspectos da vida individual e social.

A laicidade justamente surge no limiar da separação do poder político para com o poder religioso, não tendo um sentido unívoco. Com o passar dos tempos, a laicidade foi aprimorada, sendo, em França, percebida a alocação prática do termo (Heinen, 2009, p. 256-257). A base do princípio da neutralidade religiosa e ideológica do Estado busca dar exatamente a liberdade às pessoas para optar ou não entre os diversos credos ou ideologias existentes, ampliando, tanto quanto possível, estas liberdades nos diversos contextos sociais e institucionais, favorecendo o pluralismo de ideias e proibindo condutas tais como: a doutrina forçada, a afirmação positiva de crenças ou a discriminação religiosa e/ou ideológica ${ }^{6}$.

Disso se extrai apenas um princípio de neutralidade institucional e procedimental dos poderes públicos diante das diferentes visões religiosas e ideológicas, buscando garantir o exercício dos direitos e evitar arbitrariedades e discriminações à luz da defesa dos princípios do Estado Constitucional. Exemplifica-se esta necessidade de forma simples: caso uma freira católica

5 Jónatas Machado (2013, p. 137) defende que o Estado precisa se posicionar em razão de valores e princípios que estruturam a sua identidade e razão de ser. Destaca que uma excessiva neutralidade estatal neste caso poderia gerar ruídos constitucionais, citando como exemplo as festividades cristãs, como o Natal, a Páscoa e outros feriados religiosos, protegidos pela legislação. Diz expressamente que “[...] quando privados das suas raízes, quando desligados da sua raiz formativa de base judaico-cristã, os princípios do Estado Constitucional surgem como afirmações subjetivas, arbitrárias, socialmente construídas e precárias" (Machado, 2013, p. 137).

6 Jónatas Machado (2013, p. 137) afirma que, a partir disso e dos princípios subjacentes ao Estado Constitucional, não se deduz uma absoluta neutralidade religiosa e nem um dever de igualdade de tratamento de doutrinas, ritos ou símbolos.

Debates do NER, Porto Alegre, ANo I4, N. 24, P. I65-I94, JUl./DeZ. 2013 
seja autorizada a usar seu hábito numa escola pública, fica difícil sustentar que, neste mesmo espaço, seja proibido o uso do véu islâmico a outra mulher.

Uma estratégia constitucionalmente mais aceitável à proibição total seria a desregulação do uso de vestuário religioso nos espaços públicos, sendo que esta decisão teria o mérito de proteger pessoas de crenças religiosas pouco conhecidas, minoritárias ou não convencionais, sem prejuízo de a matriz judaico-cristã do Estado Constitucional justificar restriçōes e diferenciaçōes discricionárias, fundamentadas no uso do vestuário religioso ou não, como, por exemplo, o uso da burca em determinados espaços, com base em alguns critérios, tais como: (a) risco de extremismo religioso; (b) grau de hostilidade para com a identidade cultural da maioria do povo; (c) proteção dos direitos das mulheres, indivíduos, menores e minorias; (d) compatibilidade de valores fundamentais de igual liberdade e dignidade a todas as pessoas; e (e) garantia de coexistência pacífica entre as pessoas de diferentes visões do mundo ${ }^{7}$.

Veja-se que a constitucionalização do movimento religioso, especialmente calcado na liberdade religiosa, foi gradual, podendo ser percebidos três tipos de Estados: (a) o confessional, que opta, claramente, por adotar uma religião ${ }^{8}$; (b) os Estados separatistas, que preveem a liberdade religiosa; e (c) os Estados laicos. No Brasil, a liberdade religiosa tomou formatação de direito fundamental com maior ênfase a partir da II Grande Guerra, tendo a Constituição Federal de 1988 assim se posicionado - art. 5º, VI e VII. Logo, pode-se perceber que a garantia da liberdade religiosa convive plenamente com o Estado laico, e este ponto é nodal às conclusóes a que se chega neste artigo.

Hoje, após uma longa jornada histórica sobre o tema, tem-se um desafio a ser formado: a prática do direito fundamental à liberdade religiosa despido de um Estado religioso. Isso porque, se a Constituição Federal de 1988

7 Com base nisso, a França tem proibido o uso da burca em espaços públicos, fundamentando esta vedação em nome da dignidade da pessoa humana, mais especificamente da mulher, mesmo que muitas mulheres de origem islâmica pretendessem usá-la. Estas questôes mostram as controvérsias constitucionais que permeiam este tema e têm sido discutidas, inclusive, no contexto processual penal.

8 É o caso da Grã-Bretanha (que promove a Igreja Anglicana), da Dinamarca, da Suécia, da Finlândia, da Grécia etc.

Debates do NER, Porto Alegre, ANo I4, N. 24, P. I65-I94, JUl./DEZ. 2013 
garantiu a liberdade religiosa - erguida ao patamar de direito fundamental (Grunderrecht $)^{9}$, não pode o Estado lato sensu, em suas mais comezinhas esferas, impor uma determinada religião, o que desconsagraria um dos fundamentos do próprio Estado brasileiro, qual seja, o pluralismo ${ }^{10}$. Mas, ao mesmo tempo, ele não pode negar esta mesma manifestação religiosa, ou optar pelo ateísmo. Deve ser, como há muito repetido, neutro.

Essa neutralidade tem por fundamento último a isonomia. Logo, pode-se claramente perceber que a igualdade é uma baliza hermenêutica muito importante para a resolução do problema. Basta ver a imposição feita à impossibilidade de se discriminar um indivíduo que quer acessar um cargo público por motivos religiosos, ou por suas opiniōes de fé ${ }^{11}$.

Nunca é demais lembrar que o direito à igualdade (art. 50, "caput", $\mathrm{CF} / 88)$ "[...] não assegura nenhum comportamento específico, cujo exercício pudesse ser atrapalhado, cuja área de proteção pudesse ser 'invadida' pelo Estado." (Schwabe, 2005, p. 319). O efeito do direito fundamental em pauta continua a ser a fixação de uma determinada posição subjetiva, o que dimana o direito de resistir (Recht aufWiderstand). Sendo assim, garante-se a resistência, não à intervenção no âmbito de proteção do direito de cada qual, mas sim (e eis o ponto), ao tratamento desigual conferido pela lei - aplicação das normas pelos Poderes Públicos.

Sendo assim, o uso de símbolos religiosos em espaços públicos deve ser questionado somente quando se tenha uma restrição imotivada ao pluralismo

9 VI - é inviolável a liberdade de consciência e de crença, sendo assegurado o livre exercício dos cultos religiosos e garantida, na forma da lei, a proteção aos locais de culto e às suas liturgias;

VII - é assegurada, nos termos da lei, a prestação de assistência religiosa nas entidades civis e militares de internação coletiva.

${ }^{10}$ Art. $1^{\circ}$ A República Federativa do Brasil, formada pela união indissolúvel dos Estados e Municípios e do Distrito Federal, constitui-se em Estado Democrático de Direito e tem como fundamentos: (...) V - o pluralismo político.

${ }^{11}$ Conselho de Estado francês (CE), 28 mai. 1954, Barel et autres. Este princípio é muito utilizado para os casos de discriminação tarifária (v.g., o fornecimento de água ou o tratamento de esgoto, que tinha tarifas diferentes no caso de se ter um residente permanente ou temporário - CE, 28 abr. 1993, Comm. De Coux).

Debates do NER, Porto Alegre, ANo I4, N. 24, P. I65-I94, JUl./DeZ. 2013 
religioso (v.g. possibilidade de manifestação de todas as religiōes $)^{12}$, sem que se tenha, da mesma forma, a imposição do ateísmo. Exige-se que o Estado guarneça essas duas posições jurídicas, mantendo-as em harmonia, criando um verdadeiro "efeito de irradiação" (Ausstrablungswirkung).

Concluindo preliminarmente: o direito fundamental ao exercício de religião está incluso na noção de liberdade de crença ou de confissão. E esta última abrange, indiferentemente, a liberdade de crer ou de não crer, ou seja, de professar uma fé, ainda que para si mesmo - de forma interior -, de mantê-la em segredo, de expô-la ou de renunciar a uma crença. E ao Estado deve caber a proteção de todas estas práticas, porque privilegiar uma seria negar as demais.

Contudo, há um questionamento muito anterior a ser feito: é possível o ser humano despir-se de seus amálgamas naturalistas, enfim, de sua subjetividade? A resposta a esta pergunta é a chave para se encontrar a solução sobre a possibilidade de existência de um Estado laico ${ }^{13}$. A pretensa imparcialidade dos agentes públicos, dos educadores, dos pesquisadores pode despir-se absolutamente das prévias convicçóes de fé?

Não se pode perder de vista que as religiōes transferiram para o ordenamento jurídico, especialmente o constitucional ocidental, valores extremamente importantes para a ordem social ${ }^{14}$. Neste sentido, em relação ao Estado Constitucional brasileiro, quando se fala em princípio da dignidade da pessoa humana como norteador do ordenamento constitucional, é impossível pensá-lo desligado da questão religiosa. Quando se fala da proteção à família, seja ela entre pessoas de sexos diferentes ou do mesmo sexo, é impossível que se reflita a respeito sem o recurso à religião. Quando

12 Sendo ainda mais específico: quando exista uma determinação específica em prol de somente uma religião, em detrimento das demais.

13 Karl Gustav afirma que todas as pessoas colocam um sentido na sua vida, ou seja, que alguma coisa vem em primeiro lugar. E estas "coisas" de cunho metafísico dão sentido à força de viver, algo que consideramos como o poder supremo da vida. O psicanalista afirma que $95 \%$ dos seus pacientes tinham problemas ligados a este tema, ou seja, com as crenças do indivíduo (Kuchenbecker, 1996, p. 11).

${ }^{14}$ Muito embora haja quem defenda que a secularização ocidental possui vícios de origem, porque pauta seu desenvolvimento a partir de uma perspectiva cristã (Asad, 2009).

Debates do NER, Porto Alegre, ANo I4, N. 24, P. I65-I94, JUl./DeZ. 2013 
se pensa na doutrina da proteção integral à criança e ao adolescente, prevista pelo nosso texto constitucional, os aspectos religiosos também estão presentes, porque o que ocorreu foi uma transferência, uma apropriação pelo mundo jurídico de valores que nasceram ou foram gestados na religião, sem que ambos se confundam ou se misturem.

A vivência da democracia é inegavelmente a opção de ser livre, mas tolerante. As opçóes religiosas da maioria podem por bem legitimar as políticas públicas, quando representam a opção livre da maioria, por exemplo, sem negar, claro, a minoria. Sendo assim, a disposição de símbolos religiosos que não dimanem um preconceito ou um caráter eliminatório de outras religióes não pode ser interpretada como violadora do pluralismo.

\section{PERSPECTIVA CONTEMPORÂNEA - A CONSTITUIÇÃO FEDERAL DE 1988 - "LAICIDADE À BRASILEIRA"}

A Constituição Federal de 1988 disciplina a liberdade de religião no inciso VIII do art. $5^{\circ}$ da Constituição Federal de $1988^{15}$. Este dispositivo deve garantir dois direitos: tanto a liberdade de crença como a liberdade de culto, porque ambas representam formas de manifestação exterior da religião professada. E, como direitos fundamentais que são, podem bem sofrer limitações ${ }^{16}$. Tanto deve ser garantido o direito de um cidadão orar (em silêncio) em uma praça pública, como se deve franquear a um grupo de cidadãos que possa orar na mesma praça, estando, neste último caso, a exercer o direito de culto.

${ }^{15}$ Art. $5^{\circ}$ [...] VIII - ninguém será privado de direitos por motivo de crença religiosa ou de convicção filosófica ou política, salvo se as invocar para eximir-se de obrigação legal a todos imposta e recusar-se a cumprir prestação alternativa, fixada em lei.

16 Segundo denuncia Emerson Giumbelli, a doutrina nacional analisa os limites do direito fundamental à religião de forma superficial, resultado da disposição deste direito de maneira estritamente formal. Destaca que as pesquisas feitas sobre o tema "[...] resultaram em um número escasso de registros [...]" que "[...] oscilam entre exegeses constitucionais e comentários casuísticos ou restritos a aspectos bem circunscritos”. Dessa forma, no país "[...] passa-se do extremamente genérico ao demasiadamente particular quando se trata de religião nas discussōes jurídicas” (2002, p. 232).

Debates do NER, Porto Alegre, ANo I4, N. 24, P. I65-I94, JUl./DeZ. 2013 
Esta diferença fica sem maior importância, porque ambas as manifestações ganham liberdade pela Carta Política de 1988, como visto (Leite, 2008).

E perceba que a Constituição Federal não alocou qualquer restrição ao livre exercício da religião. Não dispôs que seu exercício deve respeitar questões como "ordem pública", "bons costumes" etc. O legislador constituinte não condicionou o exercício deste direito a nenhuma outra premissa. O que significa dizer que ela somente será aceita se cotejada com outro dispositivo constitucional - de mesma hierarquia. Não se pode, p. ex., sob o fundamento de que se está a exercer o direito de religião, admitir a degradação do meioambiente, bem jurídico igualmente protegido pela $\mathrm{CF} / 88^{17}$.

Sendo assim, é importante que se condense uma primeira noção: o direito ao exercício da religião e ao respeito a ela deve ser interpretado de forma extensiva, ou seja, pró-religiāo (em favor do seu exercício e em qualquer âmbito). Na mesma medida, não se aceitam soluções a priori, devendo haver uma análise mais detida de certas peculiaridades do caso concreto, o que dimana o entendimento de que a laicidade não importa por si só na retirada dos símbolos religiosos. Até porque a Constituição Federal, em geral, não pode ser vista a priori.

O tal princípio da laicidade veio detalhado da seguinte maneira no texto constitucional vigente:

Art. 19. É vedado à União, aos Estados, ao Distrito Federal e aos Municípios: I - estabelecer cultos religiosos ou igrejas, subvencioná-los, embaraçar-lhes o funcionamento ou manter com eles ou seus representantes relações de dependência ou aliança, ressalvada, na forma da lei, a colaboração de interesse público

Nada mais lógico, a partir daí, do que interpretar este dispositivo a partir de quem detém a última palavra a respeito: a nossa Corte Constitucional,

${ }^{17}$ Um caso de fiscalização e regulação do direito de livre exercício da religião pode ser conferido a partir do texto do art. $2^{\circ}$, Decreto no $43.252 / 2004$, editado pelo Governador do Rio Grande do Sul, que regulamenta o Código Estadual de Proteção aos Animais: "Para o exercício de cultos religiosos cuja liturgia provém de religiôes de matriz africana, somente poderão ser utilizados animais destinados à alimentação humana, sem utilização de recursos de crueldade para a sua morte".

Debates do NER, Porto Alegre, ANO I4, N. 24, P. I65-I94, JUl./DEZ. 2013 
leia-se: Supremo Tribunal Federal (STF). Nesse contexto, uma manifestação de laicidade adveio do julgamento que afirmou a irrelevância jurídica do preâmbulo constitucional, apesar de fazer alusão à "proteção de Deus"18. Nessa decisão, entendeu-se, com base na doutrina de Jorge Miranda, que o preâmbulo não cria direitos, sendo mero texto de valor axiológico, das aspirações da sociedade ${ }^{19}$. A conclusão do voto do Ministro-Relator perfilha o entendimento de que: "A Constituição é de todos, não distinguindo entre deístas, agnósticos ou ateístas".

E assim deve ser o Estado. E assim devem ser as conclusões deste artigo. Antecipam-se, então, alguns pontos a serem ainda explorados na sequência: a Constituição Federal de 1988 não determinou a postura ateísta, negadora dos símbolos religiosos em repartições públicas, da mesma forma que não propugnou pela promoção de uma determinada religião. E esta harmonia consagra com franqueza o pluralismo, elemento nodal do Estado Democrático de Direito.

O Estado Constitucional postula a existência de Deus como uma dimensão incontornável da existência e da dignidade humana, onde se deve procurar fundamentos, sentido e limites para a vida (Machado, 2013, p. 144). Assim, este mesmo Estado deve adotar uma postura neutra acerca das questôes religiosas, pois no momento em que for adotada uma postura negativa ou positiva estar-se-á interferindo em uma ou outra seara de liberdades pessoais. A existência de Deus é uma possibilidade plenamente integrada na razão pública de um Estado, cujos valores se deduzem de premissas teístas. É esta via de raciocínio que previne qualquer tentativa de homogeneização religiosa ou cultural socialmente induzida.

18 STF, ADI, 2.076-5/AC, Rel. Min. Carlos Velloso, Pleno, j. 15/08/2002.

${ }^{19}$ Ao contrário da doutrina francesa, que entende que o preâmbulo é verdadeiro "texto constitucional”. René Chapus (2001, p. 44-45) analisa a questão com muita propriedade: ao que parece, o preâmbulo da Constituição de 1958 tem apenas um valor político, e não jurídico. Mas o Conselho de Estado francês pensa diferentemente: entende que o preâmbulo tem valor de lei constitucional e, o que é mais interessante, em sua totalidade (CE, Assoc. nat. Pour l'éthique de la médecine libérale, 30 abr. 1997; CE, GISTI, 20 abr. 1997 etc.).

Debates do NER, Porto Alegre, ANo I4, N. 24, P. I65-I94, JUl./DeZ. 2013 
Veja que não é necessário crer em Deus ou em um "Ser Supremo" para defender os valores do Estado Constitucional e viver de acordo com ele, pois tanto ateus quanto aqueles que possuem qualquer crença religiosa têm afirmadas a sua dignidade de pessoa humana, a liberdade, a responsabilidade e a justiça. Estes valores devem ser garantidos independentemente de se ter ostentado um símbolo religioso, porque partem de uma Carta de Direitos fundamental e vinculante a todos, ateus ou não. E estes valores são largamente acolhidos pelo direito internacional, cuja racionalidade só é plausível se existir a partir da moral, do racional, do justo e do bom, independentemente de ser ou não religioso.

No Estado Constitucional não devem ser retiradas afirmações de valor que esvaziem seu fundamento racional e moral, ficando entregues ao subjetivismo, ao arbítrio e à precariedade das mais diversas construções e interesses sociais. Este Estado, assim, só pode ser racionalmente sustentado a partir de um constitucionalismo neutro, não teocrático nem secularizado, indexado às afirmações do seu próprio texto, cuja base exige que o Estado seja tão generoso e inclusivo quanto sua natureza exija e lhe permita. Mas, sobretudo, este Estado deve ser tolerante.

A partir deste precedente, pode-se concluir que o simples uso de um símbolo religioso não torna o Estado confessional. O STF interpretou que a inserção do termo "sob a proteção de Deus" não retira a laicidade do Estado. Se assim o é, não se pode, da mesma forma, pensar que a simples disposição de um símbolo religioso em um espaço público pode subtrair a neutralidade da atuação do Poder Público ${ }^{20}$. Em arremate: se à nossa norma maior foi dada esta hermenêutica, não podemos fugir de outra conclusão para com o uso de símbolos religiosos nos espaços públicos.

Além disso, pode-se perceber que ocorrem inúmeras manifestações religiosas no interior dos espaços públicos, sem se estar capitaneando um verdadeiro "assédio religioso", ou seja, a evidente prática de uma religião no

${ }^{20}$ Não se nega que a laicidade seja um elemento da neutralidade da prestação dos serviços públicos, como bem expõe René Chapus (Op. Cit., p. 610). E bem por isso não podem os aparelhos estatais tomar uma ou outra conduta, privilegiando ou não a religião ou o ateísmo.

Debates do NER, Porto Alegre, ANo I4, N. 24, P. I65-I94, JUl./DEZ. 2013 
sentido de angariar ou de doutrinar fiéis. Tal prática não procura abordar outrem de forma incisiva ou insistente, no intento de impor constrangimento de ordem religiosa. Basta ver a disposição de presépios, árvores ou ornamentos de Natal, ao final de cada ano, em variados espaços de órgãos públicos ${ }^{21}$. Nunca se pensou que isto seria uma medida de assédio religioso. Ao contrário. A apresentação de um Estado laico tolera a liberdade religiosa, anexa ao pluralismo, não se vedando que qualquer outra manifestação religiosa, desde que desafeita a qualquer preconceito ou violência de qualquer ordem, possa manifestar-se em espaço comum ${ }^{22}$. Enfim, não se coaduna, como visto, com o direcionamento religioso, quiçá impositivo.

Da mesma forma, caso seja dada guarida ao entendimento de que o Estado secular deva extirpar qualquer símbolo religioso dos espaços públicos, poder-se-ia vedar a possibilidade de se permitir procissóes religiosas em vias públicas, ou mesmo a cedência de bens públicos para encontros religiosos. Assim, estaríamos, na nossa ótica, a um passo da perseguição religiosa sob a justificativa de uma "laicidade" que, no caso, não passaria de ateísmo preconceituoso, para dizer o mínimo.

A laicidade do Estado foi traduzida como um princípio fundamental da República brasileira no voto do Min. Joaquim Barbosa, proferido na Ação Direta de Inconstitucionalidade $\mathrm{n}^{\circ}$ 3.510-DF, sendo um corolário do art. $19^{23}$. Assegurou-se, ainda, que o princípio da laicidade do Estado justamente

21 Claro que sabemos que existe quem defenda esta ideia, no sentido de proibir a disposição, em espaços estatais, de todo tipo de manifestação religiosa de final de ano (árvores de Natal, presépios etc.) (Dworkin, 2006, p. 58).

22 "Sob a capa da religião não se toleram atos violadores dos direitos de outrem ou perturbadores da paz social, práticas contrárias à higiene, ofensas ao senso moral médio da humanidade civilizada" (Maximiliano, 1948, p. 378).

23 A referida ação discutia a constitucionalidade da lei que permite a pesquisa com célulastronco, matéria que traz a lume, em mais uma oportunidade, até que ponto um critério confessional pode influenciar as políticas públicas. Confira o enxerto do voto do Min. Joaquim Barbosa: “[...] Nesse ponto, creio que a lei respeita três primados fundamentais da República Federativa do Brasil inseridos na Constituição Federal: a laicidade do Estado Brasileiro (art. 19, I da CF/88), traduzida também no respeito à liberdade de crença e religião (art. 5, VI), [...]" (STF, ADI 3.510-DF, Rel. Min. Ayres Britto, Pleno, j. 29/05/2008).

Debates do NER, Porto Alegre, Ano I4, N. 24, P. I65-I94, JUl./Dez. 2013 
garante o próprio respeito à liberdade de crença e religião (consagrado no art. 5, VI, CF/88). Assim, convivem os mais diversos credos e práticas religiosas em nossa sociedade. E todos os praticantes e seguidores das mais diversas religiōes têm o direito de ver suas convicçôes religiosas respeitadas. Sendo assim, ninguém, nem mesmo o Estado, poderá obrigar as pessoas a agir de forma contrária aos seus interesses, aos seus sentimentos, às suas ideias, aos seus valores, à sua religião e à sua própria convicção acerca das questões mais comezinhas que permeiam as questôes metafísicas humanas ${ }^{24}$. Deixar que os símbolos religiosos sejam expostos nos locais públicos, desde que se reserve o direito de petição à retirada, caso exista ofensa ao direito do outro, permite, portanto, que seja consagrada incólume a esfera íntima reservada à crença das pessoas e o seu sagrado direito à liberdade.

A formatação de um Estado secular permite a liberdade de culto, ao mesmo tempo em que a religião não guiaria o tratamento dispensado aos direitos fundamentais. E a disposição de símbolos religiosos nas repartições públicas não teria condão bastante para firmar uma postura intolerante, impeditiva ao direito de autodeterminação, preconceituosa, impeditiva à liberdade de expressão etc.

Assim como a questão não pode ser colocada sob os influxos positivos de uma defesa da religiosidade do Estado, ela menos ainda pode ser percebida pela via de uma ideologia negativista, que nega qualquer valor moral. Eis a neutralidade do Estado. Não nos esqueçamos de que ele é feito, antes, de homens, detentores de convicções, de percepções, de visões de mundo. E cabe ao Estado ser tolerante a todas elas. Em uma democracia, não seria legítimo excluir qualquer ator do âmbito de definição do sentido da Constituição e dos desígnios do Estado.

Cabe ao Poder Público, portanto, como bem definido pelo Supremo Tribunal Federal, receber os argumentos provenientes dos grupos religiosos ou seculares de forma traduzida, ou seja, em termos de razões públicas. A adesão deles não depende de fé, mas de respeito a todas as outras religiōes.

${ }^{24}$ Idem, em analogia.

Debates do NER, Porto Alegre, ANo I4, N. 24, P. I65-I94, JUl./Dez. 2013 
Significa dizer que não se pode pensar que, só porque uma escola pública tem o nome de um santo católico, ela não admitirá alunos de outra religião ou sem crença alguma. Ou mesmo que ela praticará uma educação confessional. Com absoluta certeza, pode-se dizer que a Escola Estadual de Ensino Fundamental São Francisco de Assis, de Porto Alegre ${ }^{25}$, ou a Escola Estadual Santo Antônio, situada no município de Santo Antônio da Patrulha ${ }^{26}$, jamais negaram a matrícula de uma criança judia, cigana ou que se dizia ateia. $\mathrm{E}$ com certeza estes estabelecimentos de ensino nunca defenderam a premência católica sobre outras religiōes. Este é um dado significativo para pensarmos até que ponto o símbolo religioso deve ser subtraído ou pode influenciar os desígnios do Estado.

Em nova incursão: a retirada ou a manutenção dos símbolos religiosos devem ser vistas sob o enfoque de uma neutralidade. Significa dizer que a subtração dos símbolos religiosos somente deve ser praticada quando constatadas certas situações do tipo:

a. nítida promoção de uma religião negadora das demais;

a. representatividade de um preconceito;

a. prejuízo à autodeterminação ou à livre formação ideológica, cultural ou existencial das pessoas; etc.

Para ficar ainda mais escancarada a incongruência na conduta de quem defende a retirada completa - sem critério qualquer e, por assim dizer, "radical" -, de todos os símbolos religiosos dos espaços públicos, apresenta-se mais uma situação que poderia ser criada. O estado do Rio Grande do Sul tem pelo menos cinquenta e oito municípios ${ }^{27}$ que fazem referência especificamente

25 Avenida Princesa Isabel, 1160, Santana, Porto Alegre/RS.

${ }^{26}$ Rua Afonso Porto Emerim, 1655, Centro, Santo Antônio da Patrulha/RS.

27 Santa Bárbara do Sul, Santa Cecília do Sul, Santa Clara do Sul, Santa Cruz do Sul, Santa Margarida do Sul, Santa Maria, Santa Maria do Herval, Santa Rosa, Santa Tereza, Santa Vitória do Palmar, Santana da Boa Vista, Santana do Livramento, Santiago, Santo Ângelo,

Debates do NER, Porto Alegre, ANo I4, N. 24, P. I65-I94, JUl./DeZ. 2013 
a santos católicos - sem contar o número de outras cidades com nítido nome religioso $^{28}$. Todos eles deveriam mudar sua designação caso vingasse a tese aqui dita "radical”, que prima pela subtração de qualquer símbolo religioso dos espaços públicos. Municípios de alta representatividade no estado, como Santa Maria, Santa Cruz do Sul e São Borja, p. ex., estariam em desacordo com o princípio da laicidade, o que não é verdadeiro.

$\mathrm{E}$, perceba, não se tem notícia qualquer de que estas cidades tenham praticado políticas públicas que deem conta de privilegiar as congregaçōes católicas, ou mesmo perseguir ou prejudicar as demais. Ao contrário. O que prova que o símbolo religioso não necessariamente é determinante para se formatar um Estado confessional.

Aliás, e este é um ponto importante, será a conduta casuística que formatará uma prática estatal religiosa, e não a simples disposição de um símbolo em espaço público. Estes objetos são expostos de forma que a adesão a eles depende de uma crença, e não obriga que todos sejam partidários desta mesma ideia. Sobreleva-se, no caso, que uma crença não poderia conduzir à discriminação de suposta conduta daqueles que optassem por não levar fé naquele símbolo, visto que seriam opções de cunho meramente moral.

Como dito, não se tem notícia ou qualquer dado empírico que demonstre que o estado do Rio Grande do Sul tenha preterido qualquer cidadão por questōes de credo, especialmente por se dispor de uma cruz, de uma Bíblia, de uma capela etc. em um local público. Bem ao contrário.

Santo Antônio da Patrulha, Santo Antônio das Missōes, Santo Antônio do Palma, Santo Antônio do Planalto, Santo Augusto, Santo Cristo, Santo Expedito do Sul, São Borja, São Domingos do Sul, São Francisco de Assis, São Francisco de Paula, São Gabriel, São Jerônimo, São João da Urtiga, São João do Polêsine, São Jorge, São José das Missões, São José do Herval, São José do Hortêncio, São José do Inhacorá, São José do Norte, São José do Ouro, São José do Sul, São José dos Ausentes, São Leopoldo, São Lourenço do Sul, São Luiz Gonzaga, São Marcos, São Martinho, São Martinho da Serra, São Miguel das Missões, São Nicolau, São Paulo das Missões, São Pedro da Serra, São Pedro das Missōes, São Pedro do Butiá, São Pedro do Sul, São Sebastião do Caí, São Sepé (muito embora derive de uma lenda indígena, foi também aqui disposto), São Valentim, São Valentim do Sul, São Valério do Sul, São Vendelino e São Vicente do Sul.

${ }^{28}$ Como Rosário do Sul, Redentora ou Bom Jesus.

Debates do NER, Porto Alegre, ANo I4, N. 24, P. I65-I94, JUl./Dez. 2013 
Só para se ter uma ideia, no último ano, promoveram-se importantíssimas e, repare, inéditas medidas no que se refere a ações afirmativas inclusivas de minorias discriminadas por questões sexuais ${ }^{29}$ ou raciais $^{30}$.

O Estado deve atuar justamente quando as instituições públicas tomam condutas que impõem um determinado padrão de comportamento, o que não é o caso. Nunca se vedou a prática, em espaços públicos, de outras religiōes, como é o caso das típicas manifestações religiosas ligadas ao culto de Iemanjá que ocorrem em locais de natureza pública.

Pensar no radicalismo de se subtrair qualquer manifestação religiosa dos espaços públicos levaria fatalmente a se negar a assistência religiosa aos detentos e a manutenção de um local para prece em instituiçóes armadas (v.g. militares), subtraindo-se por completo o direito fundamental constante no inciso VII do art. $5^{\circ}$ da CF/88 - já analisado. No primeiro caso, sabe-se que as pastorais ou grupos religiosos de outras ordens têm desenvolvido um trabalho fundamental na ressocialização dos presos. Por outro lado, pode-se dizer que treze países das Américas contam com a presença de assistência religiosa em seus quartéis - entre eles, Colômbia, Argentina, Brasil, Chile, Canadá, Equador, Paraguai e Venezuela. Na Europa, esse número sobe para quatorze naçôes, a saber: Alemanha, Áustria, Bélgica, França, Inglaterra, Holanda, Itália, Portugal etc. (Esquivel, 2008, p. 119).

No Brasil, a prestação de assistência religiosa nas entidades hospitalares públicas e privadas, bem como nos estabelecimentos prisionais civis e militares, vem disciplinada pela Lei no 9.982/2000. Dessa forma, a norma em pauta não parece oferecer espaço para polêmicas no que tange ao envolvimento entre Estado e religião, sem que se tenha, para tanto, sequer questionado a sua constitucionalidade.

${ }^{29}$ PGE-RS, Parecer no 15.494 , de 23/08/2011 - interpreta a Constituição Federal, permitindo que fosse paga pensão aos companheiros que detinham comprovada união homoafetiva.

${ }^{30}$ PGE-RS, Parecer no 15.703, de 20/03/2012 - ganhou caráter normativo e impõe que seja garantida uma cota de vagas a afrodescendentes em concursos públicos e seleções.

Debates do NER, Porto Alegre, Ano I4, N. 24, P. I65-I94, JUl./Dez. 2013 
Vale lembrar que a Lei de Execuções Penais (Lei no 7.210/84), ainda antes da $\mathrm{CF} / 88$, já assegurava a assistência religiosa no art. $24^{31}$. E este direito é previsto mesmo na França, um país que, como visto, levou a laicidade às suas últimas consequências (Giumbelli, 2002, p. 191). A vedação constitucional de um Estado confessional não impede, como se está demonstrando, a desconsideração absoluta de aspectos históricos e culturais nas relações que, de alguma forma, aproximam Estado e religião. Certas atividades prestadas pelos Poderes Públicos podem bem atender às religióes, assim como estas podem atender ao Estado.

Essas informações provam que as entidades religiosas podem estar presentes no âmbito estatal. O que não se pode permitir é negar a presença de uma determinada congregação quando solicitada por um militar ou por um detento, ou obrigar estes a adotarem determinada religião.

Como dito: a presença de instituições religiosas em espaços públicos foi uma opção do constituinte originário, que não nega a laicidade do art. 19 , inciso $\mathrm{I}^{32}$. E este raciocínio é perfeitamente enquadrado ao caso em pauta, ou seja, no que se refere à disposição de símbolos religiosos em locais públicos. Assim, não há uma necessária antítese entre a laicidade do Estado

31 Art. 24 - A assistência religiosa, com liberdade de culto, será prestada aos presos e aos internados, permitindo-se-lhes a participação nos serviços organizados no estabelecimento penal, bem como a posse de livros de instrução religiosa. $\$ 1^{\circ}$ No estabelecimento haverá local apropriado para os cultos religiosos; $\$ 2^{\circ}$ Nenhum preso ou internado poderá ser obrigado a participar de atividade religiosa.

32 "Não é incorreto dizer que o Estado democrático ostenta o caráter agnóstico que torna possível a coexistência de diferentes religiōes, credos ou cultos. Este caráter agnóstico permite a convivência entre valores discrepantes, antípodas e, em alguns casos, excludentes. O ser agnóstico do Estado democrático faculta a qualquer um a prática de qualquer credo ou religião, e até mesmo o ateísmo. O agnosticismo do Estado democrático está inevitavelmente associado ao relativismo. Este relativismo é indispensável para a convivência dos variados credos, religiōes e cultos. Todo credo, culto ou religião é compreendido como absoluto para alguns, infalível para os seus fiéis e sempre dependendo de condicionantes históricas, axiológicas e culturais. O ser agnóstico é condição essencial da democracia por considerar incompatível com o regime - e mesmo inalcançável - qualquer valor religioso absoluto" (Borges, 2005, p. 11).

Debates do NER, Porto Alegre, ANO I4, N. 24, P. I65-I94, JUl./DEZ. 2013 
e a presença de objetos confessionais em repartições e órgãos públicos. Nem mesmo uma negativa a priori.

A evolução dos movimentos religiosos no Brasil, especialmente a partir da maturação encontrada nos últimos anos pelo movimento pentecostal, fez-se sentir na atividade política do país, atuação que foi direcionada pelos grupos religiosos aos seus interesses, nunca tendo sido levantado qualquer impedimento neste sentido. Partidos políticos que ascendem ao poder partindo de uma plataforma eleitoral e de uma política confessionais nunca foram vetados do processo de inserção no poder. E nem se poderia assim pensar, o que reforça aquilo que aqui nos esforçamos em defender: o direito à liberdade de religião é, antes de tudo e acima de tudo, um direito à tolerância.

Pensar na retirada radical dos símbolos religiosos perpassa pela noção de impedir que candidatos possam se eleger com alcunhas de "pastores", "padres", ou mesmo vedar que os religiosos possam se candidatar ao pleito, o que é um completo retrocesso social. Este é um bom exemplo que demonstra o perigo que o radicalismo que propugna ortodoxamente pela retirada completa dos símbolos religiosos pode representar. Veja que este pensamento, de acordo com o que foi amplamente demonstrado, beira o limite da intolerância, se não professa a negação ao direito de livre expressão religiosa.

Ao darmos um passo nesse sentido, abrimos espaço para tratarmos a questão não mais pautada na neutralidade que aqui propomos, mas em uma laicidade deletéria. Veja: o Poder Público tem sim políticas fomentadoras de vários credos e da prática religiosa. $\mathrm{E}$ isso não subtrai a imparcialidade da Administração Pública. Ao contrário. Assim como se fomenta o direito à saúde, à educação ou à cultura, o Estado pode bem fomentar o direito à livre expressão religiosa, sem que, com isto, repita-se, tenha-se a presença de um Estado confessional. Assim, a manutenção de símbolos religiosos em nada afeta a neutralidade ou a laicidade do Estado, assim como o fomento de políticas públicas de toda sorte no que se refere ao incentivo às práticas religiosas.

É interessante que se questione a manutenção dos símbolos religiosos em espaços públicos, mas nunca na história do nosso país se combateu a manutenção, o fomento, a subvenção e o incentivo de toda ordem à constituição de cemitérios, prática de intenso cunho religioso, sendo estes, em sua grande

Debates do NER, Porto Alegre, ANo I4, N. 24, P. I65-I94, JUl./Dez. 2013 
maioria, bens públicos, cuja utilização pelo particular segue o regime jurídico administrativo ${ }^{33}$. Municípios desapropriam terrenos, mantêm funcionários, dispensam recursos para esta prática nitidamente eclesiástica, sem que se tenha jamais feito qualquer questionamento. Dessa forma, retirar os símbolos religiosos dos espaços públicos constitui um passo deveras perigoso para a proibição da manutenção destes abrigos ao culto aos mortos.

Ademais, pensar neste "ateísmo extremo" 34 seria, da mesma forma, pensar que não é possível a veiculação de qualquer mensagem religiosa pelos canais televisivos ou radiofônicos, dado que se trata de serviço público que, na linha da tese ora exposta, deve ser estritamente secular. Assim, órgãos de fiscalização como a ANCINE deveriam censurar qualquer mensagem de fé professada pelo rádio ou pela televisão, o que, na nossa concepção, não é razoável.

Uma tomada de posição tão drástica poderia levar a outro questionamento ainda mais radical: a opção feita pelo constituinte originário, no sentido de permitir a imunidade tributária sobre templos de qualquer culto (art. 150, VI, "b" da Constituição Federal), que é, em um sentido amplo, uma renúncia de receita, quando se sabe que tal direito existe justamente para não permitir que o Estado, por meio do aumento drástico de impostos, possa impedir o livre exercício do credo $^{35}$. Mas este é um indicativo muito sólido no sentido de que o fomento a práticas religiosas não retira a laicidade do Estado. Assim como a manutenção ou não de símbolos religiosos não o torna promotor de uma ou de outra religião.

33 PROCESSUAL CIVIL E ADMINISTRATIVO - RECURSO ESPECIAL - CEMITÉRIO PÚBLICO - BEM PÚBLICO DE USO ESPECIAL - CONCESSÃO DE USO - NÃO INCIDÊNCIA DO CÓDIGO DE DEFESA DO CONSUMIDOR (CDC). 1. O ato do Poder Público que permite o uso de cemitério municipal é uma concessão de uso de bem público. 2. Ato administrativo regido por normas de direito público. 3. Recurso especial provido. (STJ, REsp 747.871/RS, Rel. Min. Eliana Calmon, Segunda Turma, j. 21/06/2007)

${ }^{34}$ Logo, na subtração completa dos símbolos religiosos de espaços públicos.

35 Claro que este dispositivo, por ser norma constitucional originária, não poderia ter sua constitucionalidade questionada no STF, além de não poder ser alterado por emenda, tendo em vista ser considerado uma cláusula pétrea.

Debates do NER, Porto Alegre, ANO I4, N. 24, P. I65-I94, JUl./DEZ. 2013 
E mais. $\mathrm{O}$ indivíduo não pode controlar a quantos símbolos religiosos será exposto na rua ou nos locais que frequenta. Esta simbologia faz parte do diálogo que todos os dias fazemos com a realidade. Admitir o controle dos símbolos religiosos nos espaços públicos está, ao nosso sentir, muito próximo do controle da abertura de mais ou menos estabelecimentos religiosos em determinada região, ou da possibilidade de veicular mais ou menos símbolos confessionais, o que é uma afronta a esta liberdade fundamental.

Outro fator que impacta é a menção a Deus feita nas cédulas do Real. Basta ler a expressão "Deus seja louvado" inscrita na moeda nacional, que, aliás, é um símbolo nacional, ou mais, uma expressão da nossa soberania. Este é um argumento ainda mais consistente ao se perceber que esta simbologia, consagrada durante toda a nossa história, nunca gerou qualquer discórdia. E, diga-se de passagem, nem sequer é rotulada como tendo um cunho promocional. $\mathrm{O}$ mais curioso é que ninguém nega fé ao valor atribuído à nossa moeda por ela ter uma simbologia confessional. Em resumo: um dos nossos maiores símbolos nacionais, representativo da nossa soberania, nunca teve um valor religioso atribuído a ele ou foi acusado de romper com o Estado laico.

Da mesma forma, nunca foi questionada a determinação do art. 79, $\$ 1^{\circ}$ do Regimento Interno da Câmara dos Deputados de se depositar uma Bíblia Sagrada "[...] à disposição de quem dela quiser fazer uso".

O mesmo não se pode dizer dos feriados religiosos estabelecidos pelo Estado lato sensu, situação que já causou toda sorte de disputas judiciais ${ }^{36}$.

${ }^{36}$ No caso dos feriados religiosos, conferir a decisão do Tribunal de Justiça do DF, que julgou constitucional a lei daquele ente federado que instituía o "Dia do evangélico": "Lei que instituiu o dia do evangélico. Constitucionalidade. Liberdade de culto. 1-A Constituição Federal, no art. 19, I, veda à União, aos Estados, ao Distrito Federal e aos Municípios estabelecer cultos religiosos ou igrejas, subvencioná-los, embaraçar-lhes o funcionamento ou manter com eles ou seus representantes relaçôes de dependência ou aliança. 2 - Não proíbe que algum desses entes da Federação, no exercício de sua competência legislativa, institua data comemorativa, a exemplo do que fez o Distrito Federal, quando instituiu o dia do evangélico. 3 - Não é, portanto, inconstitucional lei assim editada. $\mathrm{E}$ os atos cometidos com base nela são válidos, como sói acontecer com a comemoração do dia do evangélico, que se caracteriza como exercício regular de um direito - ao culto religioso (CF, art. $\left.5^{\circ}, \mathrm{VI}\right)$. E quem exerce um direito, salvo abuso, não

Debates do NER, Porto Alegre, Ano I4, N. 24, P. I65-I94, JUl./Dez. 2013 
A Lei $\mathrm{n}^{\circ} 9.093 / 95$, de natureza nacional, disciplinou o estabelecimento de feriados civis. Determinou que podem ser considerados como "feriado religioso" (cuide-se) "[...] os dias de guarda, declarados em lei municipal, de acordo com a tradição local e em número não superior a quatro, neste incluída a Sexta-Feira da Paixão”. Assim, o Estado acabou por disciplinar as competências e conferir uma institucionalização de feriados ligados a comemoraçōes religiosas.

Só para se ter uma ideia da complexidade da questão, o Tribunal de Justiça do Estado do Rio Grande do Sul declarou inconstitucionais as leis municipais que fixavam como feriado o dia 20 de novembro, dia em homenagem a Zumbi dos Palmares. A Corte de Justiça, a partir de um argumento deveras duvidoso, alegou que a data não tinha "conotação religiosa", sendo que a lei nacional apenas permitia às municipalidades instituir feriados respaldados em eventos desta natureza ${ }^{37}$.

A questão transborda a tal ponto que, no município de Porto Alegre, foi aprovada uma lei (no 10.010, de 06/07/2006) que franqueia aos alunos da rede escolar regular municipal "[...] a transferência de datas de trabalhos e exames acadêmicos, bem como quaisquer atividades curriculares em dias não coincidentes com o período de guarda religiosa" (art. 2o), o que abrange não apenas os feriados judaicos, mas também o sábado, como dia de guarda.

Assim, por tudo o que foi exposto, entende-se que os limites do quadro constitucional vigente permitem que elementos ideológico-religiosos sejam dispostos em locais públicos, sem que isso ofenda a laicidade ${ }^{38}$. A cruz, o

causa dano a outrem (CC, art. 160, I). 4 - Vislumbrar em situações que tal preceito ou discriminação é emprestar razão à intolerância religiosa, praga que, ao longo da história, tem feito e continua fazendo inúmeras vítimas. 5 - Apelação não provida.” (TJ-DF, Proc. 20010110875766, 4. a Turma Cível)

37 TJ-RS, ADI’s n. 70007609308, 70007609407 e 70007611650 , Órgão Especial, j. em 18/10/2004. Ou: TJ-RS, ADI n. 70010191815, Órgão Especial, j. 21/02/2005.

38 Como já autorizado pelo Superior Tribunal de Justiça: "Aeroporto - Autorização para a realização de congresso religioso - Ato discricionário. I - O Ministro da Aeronáutica cedeu o Campo de Marte, em São Paulo, para que lá se realizasse o Segundo Congresso Mundial das Assembléias de Deus. Quando tudo estava agendado, com divulgação nacional e internacional, o Aeroclube de São Paulo e outras entidades impetraram segurança para a

Debates do NER, Porto Alegre, ANO I4, N. 24, P. I65-I94, JUl./DEZ. 2013 
presépio, a árvore de Natal, batizar uma cidade ou um departamento com o nome de um santo, mencionar Deus na moeda nacional, permitir e fomentar cemitérios, nominar ruas com conotação confessional, franquear ao serviço público televisivo ou radiofônico a veiculação de mensagens de fé, autorizar que presídios tenham um espaço religioso ou a presença de um pregador, e tantos outros exemplos dados, não são um instrumento de promoção de determinada religião, ou mesmo não vêm a romper com a laicidade do Estado.

A religião e a cultura fazem parte da realidade e da vida de muitas pessoas. Não que elas conectem-se diretamente a todos os sujeitos, mas perpassam naturalmente pelos espaços de convívio mútuo (v.g. uma igreja disposta em frente a uma praça é um símbolo religioso que convive com todos aqueles que frequentam esta área coletiva, independentemente de se ter ou não credo). Assim como podemos perceber reiteradamente manifestaçôes culturais nos espaços públicos (p. ex., exposições, uso de determinados adereços, disposição de objetos culturais nas paredes etc.), bem podemos admitir manifestações religiosas de toda ordem.

Negar o espaço público a uma manifestação religiosa será o mesmo que negar que se possa manifestar em ambiente público determinada convicção sexual. Não raras vezes foram penduradas, em espaços estatais, bandeiras e adereços alusivos à ideologia homossexual. Da mesma forma que o Estado não pode impedir o ateísmo ou a convicção religiosa, não pode subtrair, dos espaços públicos, as mais variadas manifestações ideológicas, inclusive as que pregam determinada orientação sexual.

Pensar o contrário do que aqui sustentamos é pensar que uma manifestação feminista em órgão público violaria os direitos do indivíduo masculino, o que é irreal e ilógico. Assim (veja o disparate!), seria proibida a utilização de

não-realização do evento religioso. O ministro-relator concedeu a liminar requerida pelos impetrantes. A Convenção-Geral das Assembléias de Deus no Brasil interpôs, então, o presente agravo regimental, instando na cassação da liminar. II - O ato da autoridade coatora (Ministro da Aeronáutica) não desborda dos lindes de sua discricionariedade: ele é quem sabe se pode, ou não, ceder o aeroporto para a realização do congresso religioso. Invocação de precedente extrajudicial (utilização do mesmo local, quando da visita do Papa, em 1980): oportunidade, ainda que desinfluente para a solução do caso concreto. III - Agravo regimental provido.” (STJ, AgR MS 5.407, Rel. Min.)

Debates do NER, Porto Alegre, ANo I4, N. 24, P. I65-I94, JUl./DeZ. 2013 
uma praça (bem público) para a reunião e/ou protesto pacífico que pregasse melhores condições de trabalho para as mulheres.

Em uma conclusão importante: os espaços públicos devem estar abertos a todas as manifestaçôes ideológicas, culturais, religiosas, agnósticas etc., desde que, por óbvio, não sejam violadoras dos direitos fundamentais, preconceituosas ou excludentes.

Entendo que a questão não pode ser tratada de forma extrema, ou seja, garantindo-se uma ausência absoluta dos símbolos religiosos. A partir do debate norte-americano, um dos mais ricos, justamente porque considera as peculiaridades dos casos concretos, estabelecem-se soluçôes a partir de premissas lógicas - p. ex., presépio em uma praça, durante o Natal; monumento (de duas toneladas) dos Dez Mandamentos na entrada de um tribunal etc. Tudo isso deve ser avaliado, caso a caso.

De acordo com os julgados do Tribunal Constitucional Federal alemão ${ }^{39}$ : o direito fundamental à liberdade religiosa pressupõe duas percepçôes: a interna e a externa. Tanto se protege o direito fundamental a ter uma determinada conviç̧ão religiosa, uma determinada fé, como característica da intimidade de cada ser humano [perspectiva interna], como se defende a possibilidade de este mesmo ser manifestar-se, expor, professar a sua fé [perspectiva externa]. Dessa maneira, negar a possibilidade de expor, de forma plural - universal -, os símbolos religiosos em espaços públicos, desde que guardadas algumas condições - já expostas - viola a perspectiva externa do direito fundamental à religião.

A noção de laicidade, como já foi assinalado, desponta como o principal fundamento para os detratores da presença de símbolos religiosos em recintos estatais. De acordo com aquilo que foi amplamente dissertado, trata-se de uma noção que merece ser problematizada de acordo com a realidade jurídica, social e, principalmente, contemporânea. $\mathrm{O}$ caso francês é elucidativo neste sentido, especialmente por ser um alerta aos riscos sociais que deste ato podem advir. A meu ver, é preciso considerar as várias situações acerca da presença das religiôes nos espaços públicos, de acordo com

39 BVferfGE 12, 1 [3], BVferfGE 24, 236 [245]; BVferfGE 24, 236; BVerfGE 93, 1 (1991). Retirado de: Schwabe (2005, p. 366-376).

Debates do NER, Porto Alegre, ANO I4, N. 24, P. I65-I94, JUl./DEZ. 2013 
as especificidades de cada situação. A avaliação, neste sentido, pressupõe considerar certos fatores:

a. o contexto social e histórico em que está inserido o símbolo religioso ${ }^{40}$;

b. a harmonia ou ponderação da liberdade religiosa negativa e positiva;

c. a necessária impossibilidade de se subtrair a autonomia de vontade do cidadão no livre exercício da sua religiosidade ou do seu ateísmo, sem que, para tanto, seja subtraído o caráter pluralista das religiōes;

d. a relação que a sociedade mantém com aquele símbolo disposto em local público.

O exercício da religião tem significado central em praticamente todas as regiões brasileiras e, mais ainda, em face da sua importância histórica, devendo ser interpretado extensivamente ${ }^{41}$. Desta interpretação extensiva fazem parte a observância da liberdade de culto, coleta de contribuições, oraçôes, recebimento de sacramentos, hasteamento de bandeiras, exercício de procissões, possibilidade de se constituir festas laicas e religiosas. Não se trata, é claro, de reconhecer, a priori, que premissas religiosas ou seculares hão de prevalecer sempre sobre a norma estatal, ou uma sobre a outra.

Inserções confessionais podem ser percebidas claramente nos preâmbulos das constituições de vários países, mencionando símbolos religiosos como, por exemplo, a invocação de Deus. Mas nem por isso o Estado deixa de ser laico. Assim, a disposição de um símbolo religioso em um espaço

${ }^{40}$ Um exemplo sugestivo desse item são as estátuas e os símbolos religiosos que, há longa data, estão expostos em locais públicos; ou práticas religiosas tradicionais em locais públicos, como o uso de presépios que, salvo melhor juízo, não traduzem o Estado em um ator promocional da religião cristã.

41 BVferfGE, 24, 236.

Debates do NER, Porto Alegre, ANo I4, N. 24, P. I65-I94, JUl./DeZ. 2013 
público não necessariamente torna o Estado confessional. Será o caso concreto que informará se há ou não um caráter promocional em cada situação.

Assim, é possível sustentar a legitimidade de um símbolo religioso em local público. Sua presença pode ser justificada quando não seja compreendida como um endosso estatal a determinada crença. Uma homenagem histórica e secular a determinado grupo religioso não necessariamente retirará a neutralidade estatal. E isso pode ser percebido factualmente na entrada das cidades, quando se dispóem, em locais públicos, estátuas de santos católicos, monumentos com símbolos maçônicos, um símbolo judaico em homenagem às vítimas do holocausto, uma estátua a Ogum, santidade da Umbanda (disposta em praça de Caxias do Sul) etc ${ }^{42}$. Agora, esta "homenagem" feita pelo monumento estaria despropositada se fosse disposta, talvez, em outros locais e de outra forma.

Aliás, o exemplo mais claro dessa razoabilidade que aqui se propugna consiste na manutenção, em local público e com recursos estatais, do Cristo Redentor (RJ), considerado uma das "maravilhas do mundo moderno". Não há como negar que se trata de uma representação religiosa cristã. Mas, objetivamente, sua importância se destacou dos limites religiosos, ganhando uma compreensão turística, histórica e social muito mais intensa. Ora, "o Cristo", como é carinhosamente chamado pelo povo brasileiro, já tomou outras proporções, a ponto de ser considerado um símbolo nacional, pertencente à história do nosso país, ainda que se faça um juízo de valor sobre o seu conteúdo. Além disso, não se percebe que o monumento ganhe a conotação promocional de uma única religião, negadora das demais.

E poder-se-ia transportar a realidade carioca ao Rio Grande do Sul. O município de Farroupilha/RS, p. ex., alberga, em local público, uma estátua da Nossa Senhora de Caravaggio, representando uma forte cultura do local. A procissão anual, que ocorre no santuário da cidade, é referência nacional. Entende-se que a disposição desse símbolo católico não ofende a secularidade estatal, mas promove os valores constitucionais da liberdade religiosa,

42 Aliás, para não deixar passar em branco, o Ogum, que corresponde ao São Jorge, é adotado como símbolo de várias Brigadas Militares do país.

Debates do NER, Porto Alegre, ANo I4, N. 24, P. I65-I94, JUl./DEZ. 2013 
cultural e artística, sem que se negue ou ponha em risco o direito - também constitucional - à tolerância religiosa.

Portanto, a (i)legitimidade dos símbolos religiosos em locais públicos deverá ser vista no caso concreto, a partir de elementos factuais e circunstanciais, revelados pela sua adequação para com os valores constitucionais incidentes.

\section{CONSIDERAÇÕES FINAIS}

Pelo exposto, conclui-se que:

1. O Estado brasileiro é neutro, não sendo nem religioso, nem ateu, ou seja, é ou deve ser tolerante.

2. As questôes envolvendo o embate axiológico-jurídico entre a laicidade e as premissas religiosas possuem importância em outras situaçōes, que não somente a perspectiva da disposição de símbolos religiosos em espaços públicos; aliás, considera-se ser este um debate que releva apenas a superfície do problema.

3. A igualdade é princípio que parametriza a ação do Estado, não podendo este atuar de forma extrema, ou seja, nem promovendo uma determinada religião, nem promovendo o ateísmo, o que revela sua característica essencial da neutralidade.

4. O direito fundamental ao exercício de religião está incluso na noção de liberdade de crença ou de confissão. E esta última abrange, indiferentemente, a liberdade de crer ou de não crer, ou seja, de professar uma fé, ainda que para si mesmo - de forma interior -, de mantê-la em segredo, de expô-la ou de renunciar a uma crença. E ao Estado deve caber a proteção de todas estas práticas, porque privilegiar uma é negar as demais.

5. A partir do texto da Constituição Federal de 1988, a laicidade não necessariamente impõe, a priori, a retirada de qualquer símbolo ou

Debates do NER, Porto Alegre, ANo I4, N. 24, P. I65-I94, JUl./Dez. 2013 
manifestação religiosa em locais públicos - interpretação de completude a partir do art. $5^{\circ}$, inciso VII, art. 19 , inciso I e art. $210, \$ 1^{\circ}$.

6. É possível a manutenção dos símbolos religiosos nos espaços públicos desde que sejam levados em conta:

6.1 O contexto social e histórico em que está inserido o símbolo religioso;

6.2 A harmonia ou ponderação da liberdade de religião negativa e positiva;

6.3 A necessária impossibilidade de se subtrair a autonomia de vontade do cidadão no livre exercício da sua religiosidade ou do seu ateísmo ${ }^{43}$, sem que, para tanto, seja subtraído o caráter pluralista das religiōes;

6.4 A relação e a afetividade que a sociedade mantém com aquele símbolo disposto em local público.

7. Caso algum cidadão entenda que sua liberdade religiosa tenha sido violada, bem como se verifique alguma das situações expostas no item "6", pode requerer, de maneira fundamentada - como corolário ao direito de petição (art. 50, inciso XXXIV, alínea “a”, CF/88) -, que esta situação seja corrigida pela Administração Pública.

8. Os espaços públicos devem estar abertos a todas as manifestações ideológicas, culturais, religiosas ou não etc., desde que esta manifestação não promova concretamente o preconceito, seja excludente ou violadora dos direitos fundamentais.

43 A título de exemplo, considera-se possível que, nos espaços públicos, seja permitido ao cidadão e ao funcionário público o porte de objetos confessionais.

Debates do NER, Porto Alegre, ANO I4, N. 24, P. I65-I94, JUl./DEZ. 2013 


\section{REFERENNCIAS}

ASAD, Talal. Genealogies of Religion: Discipline and Reasons of Power in Christianity and Islam. Baltimore: Johns Hopkins University Press, 1993. Is Critique Secular? Blasphemy, Injury and Free Speech. Berkeley: University of California Press, 2009.

BORGES, Alexandre Walmott. Considerações sobre a vedação constitucional do artigo 19, I, CF/88 - O Estado Laico. Revista Jurídica da Universidade de Franca, Franca, ano 8, n. 14, jan./jun. 2005.

CHAPUS, René. Droit administratifgeneral-t. 1. Paris: Montchrestien, 2001.

DWORKIN, Ronald. Is democracy possible here? Princeton: Princeton University Press, 2006.

ESQUIVEL, Juan Cruz. A marca católica na legislação argentina. O caso da assistência religiosa nas Forças Armadas. In: LOREA, Roberto Arriada (Org.). Em defesa das liberdades laicas. Porto Alegre: Livraria do Advogado, 2008.

GIUMBELLI, Emerson. O Fim da Religião - dilemas da liberdade religiosa no Brasil e na França. São Paulo: Attar Editorial, 2002.

HUACO, Marco. A laicidade como princípio constitucional do Estado de Direito. In: LOREA, Roberto Arriada (Org.). Em defesa das liberdades laicas. Porto Alegre: Livraria do Advogado, 2008.

KUCHENBECKER, Valter (Coord.). O homem e o sagrado. A religiosidade através dos tempos. Porto Alegre: Editora da Ulbra, 1996.

LEITE, Fábio Carvalho. Estado e Religião no Brasil-a liberdade religiosa na Constituição de 1988. Tese (Doutorado em Direito Público) - Universidade do Estado do Rio de Janeiro, Rio de Janeiro, 2008.

LOCKE, John. A letter concerning toleration. New York: Prometheus Books, 1990.

LOREA, Roberto Arriada (Org.). Em defesa das liberdades laicas. Porto Alegre: Livraria do Advogado, 2008. Resenha de: HEINEN, Juliano. Em

Debates do NER, Porto Alegre, ANo I4, N. 24, P. I65-I94, JUl./Dez. 2013 
defesa das liberdades laicas. Debates do NER, Porto Alegre, ano 10, n. 16, jul./dez. 2009.

MACHADO, Jónatas E. M. Estado Constitucional e Neutralidade Religiosa. Entre o teísmo e o (neo)ateísmo. Porto Alegre: Livraria do Advogado Editora, 2013.

MAXIMILIANO, Carlos. Comentários à constituição brasileira - v. 1. São Paulo e Rio de Janeiro: Freitas Bastos, 1948.

PONTES DE MIRANDA, Francisco Cavalcanti. Democracia, Liberdade e Igualdade - Os três caminhos. Rio de Janeiro: José Olympio, 1945.

SCHWABE, Jürgen. Cinqüenta anos da jurisprudência do Tribunal Constitucional Alemão. Montevidéu: Fundação Konrad-Adenauer, 2005. 